\title{
Mechanism of the Protective Action of Anti-Salmonella IgM in Experimental Mouse Salmonellosis
}

\author{
By HARRI SAXÉN \\ National Public Health Institute, Mannerheimintie 166, SF-00280 Helsinki 28, Finland
}

(Received 23 February 1984; revised 4 May 1984)

\begin{abstract}
The kinetics of mouse salmonellosis caused by Salmonella typhimurium was studied in mice preinjected with the IgM or IgG fraction prepared from a rabbit anti-Salmonella serum. Compared on the basis of antibody units determined by an enzyme immunoassay, IgM was ten times more effective than IgG in promoting removal of the bacteria from blood after intravenous (IV) injection and their uptake in the reticuloendothelial system (RES). The subsequent killing of the bacteria was, however, only minor, in accord with the negligible protective effect of serum antibodies in IV infection. IgM was over 1000 times more effective than IgG in promoting killing of the bacteria after intraperitoneal (IP) challenge. Neither antibody had an effect on the multiplication of the bacteria in the RES. The protective action of antibody was thus almost entirely mediated by peritoneal-cavity cells acting in the very early phase of infection. The greater effect of IgM is suggested to be a special feature of Salmonella infections, connected with the capacity of these bacteria for intracellular survival and multiplication in the RES.
\end{abstract}

\section{INTRODUCTION}

Mouse salmonellosis has been extensively studied as a model of an infection caused by facultatively intraphagocytic bacteria (Ørskov et al., 1928; Jenkin \& Rowley, 1963; Mackaness et al., 1966; Collins et al., 1966), but many questions still remain open. Thus, genetic differences in both the host (Webster, 1937; Biozzi, 1972; Plant \& Glynn, 1976; O'Brien et al., 1979; Hormaeche et al., 1980) and the pathogen (Ørskov \& Moltke, 1928; Roantree, 1967; Valtonen, 1970; Hoiseth \& Stocker, 1981) influence the outcome of the infection, but their exact mechanism of action is known only in the specific instance of genes causing a nutritional defect in the bacteria. Both cellular and humoral immunity play a role in the defence but their relative contributions are still under debate (Levine \& Hornick, 1981). The route of infection influences the course of the infection, but we do not know, for example, why intraperitoneally (IP) induced infection is more easily prevented by antibodies than is infection after intravenous (IV) challenge (Mackaness et al., 1966; Jenkin \& Rowley, 1963; Blanden et al., 1966).

Recent studies in this laboratory have revealed a further unexplained feature of experimental mouse salmonellosis: the antibodies protective against IP challenge were primarily of the IgM class (Saxén \& Mäkelä, 1982; Saxén et al., 1984b). This was true of antibodies of rabbit or mouse origin, induced by immunization with whole smooth bacteria, with cell envelopes of a rough mutant or with a semi-synthetic antigen in which an $\mathrm{O}$-antigen-specific oligosaccharide was conjugated to an unrelated protein, diphtheria toxoid. Many of these sera contained approximately equal amounts of IgM and IgG anti-Salmonella antibodies, but some had much more IgG than IgM.

Why IgM has this special position in Salmonella infections is not clear. I have now approached this question by comparing the effects of anti-O-antibodies of the IgM and IgG class on the kinetics of the infection.

\footnotetext{
Abbreviations: IP, intraperitoneal(ly); IV, intravenous(ly); $\mathrm{LD}_{50}, 50 \%$ lethal dose; $\mathrm{RES}$, reticuloendothelial system.
} 


\section{METHODS}

Bacteria. The smooth, moderately mouse-virulent Salmonella typhimurium LT2 strain SH2183 with the Oantigenic formula 4,5,12 grown to late exponential phase $\left(2 \times 10^{9}\right.$ bacteria $\left.\mathrm{ml}^{-1}\right)$ at $37^{\circ} \mathrm{C}$ under aeration in $\mathrm{L}$ broth (Miller, 1972) was used in all experiments. Its $50 \%$ lethal dose $\left(\mathrm{LD}_{50}\right)$ when given IP to the mouse strain used was $2 \times 10^{5}$, assayed as described by Valtonen (1970).

Mice. $(\mathrm{CBA} \times \mathrm{C} 57 \mathrm{Bl} / 6) \mathrm{F}_{1}$ mice (6 to 8 weeks old) bred at this institute were used in all assays.

Antibody fractions. The hyperimmune rabbit serum K 2249 and its fractions were derived as described by Saxén \& Mäkelä (1982). The immunogen was heat-killed whole smooth $0-4,5,12 \mathrm{~S}$. typhimurium (approximately $10^{8}$ bacteria per injection) injected in the footpads seven times over a period of 8 weeks. The IgG and the IgM plus IgA fractions were prepared from separate samples of serum. The IgG fraction was obtained by removing IgM and IgA by adsorption to DEAE-cellulose in $0.01 \mathrm{M}$-phosphate buffer, $\mathrm{pH} 8.0$, and the IgM plus IgA fraction by adsorption of IgG to protein A-Sepharose. The contribution of IgA to the protective action of this serum was negligible (Saxén \& Mäkelä, 1982), and thus the IgM plus IgA fraction was used as representative of IgM.

Enzyme immunoassay. The assay was performed exactly as described before using 0-4,5,12 LPS antigen (Saxén \& Mākelä, 1982). The serum fractions were titrated in half-log dilutions and binding was detected with an alkaline phosphatase conjugated anti-rabbit-immunoglobulin (Orion Diagnostica, Espoo, Finland). The titre was taken as the dilution that gave an $\boldsymbol{A}_{\mathbf{4 0 0}}$ of $\mathbf{0 . 4}$, and its reciprocal used to define the antibody concentration in enzyme immunoassay units $\left(100\right.$ units $\left.\mathrm{ml}^{-1}\right)$ corresponding to a titre of 1 in 100 .

Blood clearance assay (Krishnapillai \& Karthigasu, 1969). The mice received half-log dilutions of the antibody fractions (or saline) via the lateral tail-vein in a volume of $200 \mu \mathrm{l}$, followed $1 \mathrm{~h}$ later by radiolabelled bacteria given by the same route. The bacteria were iodinated ( $\mathrm{Na}^{125} \mathrm{I}$, Amersham) just before use by the 1,3,4,6-tetrachloro3 $\alpha, 6 \alpha$-diphenylglycoluril (Iodo-Gen, Pierce Chemical Co., Rockford, Ill., USA) method (Fraker \& Speck, 1978). The injected dose contained $10^{8}$ bacteria $\left(2 \times 10^{5}\right.$ c.p.m. $)$ in $200 \mu$ l. At various times after this, blood samples $(50 \mu \mathrm{l}$ each) were taken from the retro-orbital plexus under ether anaesthesia.

The mice were sacrificed by cervical dislocation at given times up to $15 \mathrm{~min}$ post challenge, and the livers and spleens removed. The specific activity of all the samples was determined in a gamma counter. For the calculations, the blood volume of a mouse was taken as $2 \mathrm{ml}$. Each point in the figures represents the geometric mean of the results from three mice.

Enumeration of viable bacteria in the tissues. Tenfold dilutions of the antibody fractions or saline were injected (IP) into mice in a volume of $200 \mu \mathrm{l}$, followed $3 \mathrm{~h}$ later with the challenge $\left(500 \mu \mathrm{l}\right.$ usually containing $2 \times 10^{6}$ bacteria per mouse) corresponding to $10 \times \mathrm{LD}_{50}$. In some experiments, both the antibody and challenge injections were given IV, each in a volume of $200 \mu \mathrm{l}$. The mice were kept in groups of six, and killed for sampling at the times indicated. Blood samples were taken as in the clearance assay. The fluid in the peritoneal cavity was collected by careful rinsing with $2 \mathrm{ml}$ PBS (Jenkin \& Rowley, 1965). The liver and spleen were cut out, put in plastic bags with $10 \mathrm{ml}$ sterile PBS and homogenized for $2 \mathrm{~min}$ in a Colworth Stomacher 80 (Seward, London, UK). Tenfold dilutions of all the samples were subsequently prepared in water for viable counts and the numbers of viable bacteria per organ were calculated. Each point in the figures represents the geometric mean of the results from three mice.

Mouse protection assay. Groups of six mice were challenged with $200 \mu$ l of tenfold dilutions of the bacterial culture given IP or IV, as indicated, and the numbers of deaths were recorded during the following $10 \mathrm{~d}$. To assay protection, parallel groups of mice were injected IP with $200 \mu$ PBS, or the antiserum K2249 diluted 1 in $30,3 \mathrm{~h}$ before or $24 \mathrm{~h}$ or $48 \mathrm{~h}$ after challenge, as indicated.

\section{RESULTS}

\section{Effect of the antibodies on IV injected salmonellae}

The opsonization activity of the rabbit IgG and IgM antibody fractions, both of which gave enzyme immunoassay titres $1: 700$ to homologous LPS, corresponding to 700 units of antibody $\mathrm{ml}^{-1}$ (Saxén \& Mākelä, 1982), was compared in an in vivo opsonization assay. Without antibody, the radiolabelled bacteria were slowly cleared from the blood; $50 \%$ of the label was still present in the blood $15 \mathrm{~min}$ after injection, whereas in the presence of either antibody fraction, most of the label had disappeared from the blood within $5 \mathrm{~min}$ (Fig. $1 \mathrm{a}$ ). At the same time, a large part of the label appeared in the livers of antibody-treated mice (Fig. $1 b$ ). When the effect of the two Ig fractions was assessed $5 \mathrm{~min}$ after challenge, IgM was tenfold more potent than IgG in accelerating the blood clearance and the liver uptake of the radiolabelled bacteria (Fig. 2).

Two hours after IV injection of $4 \times 10^{5}$ bacteria, none were found in the blood. The numbers of viable bacteria in the liver and spleen (Fig. 3) indicated very little, if any, immediate killing. 


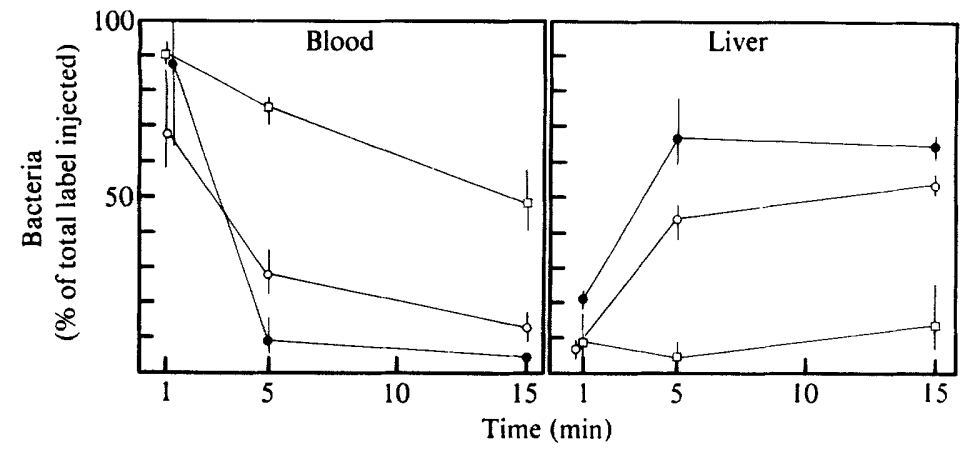

Fig. 1. Effect of anti-Salmonella IgG or IgM antibodies on the blood clearance of radiolabelled $S$. typhimurium shown as the fraction of label remaining in the blood or taken up by the liver at 1-15 min after IV injection. The mice received saline $(\square)$ or 20 antibody units of the $\operatorname{IgG}(O)$ or the IgM $(O)$ fraction of the anti-S. typhimurium antiserum IV $1 \mathrm{~h}$ before challenge. Each point represents the geometric mean of results for three mice; the vertical line shows the scatter between the values.

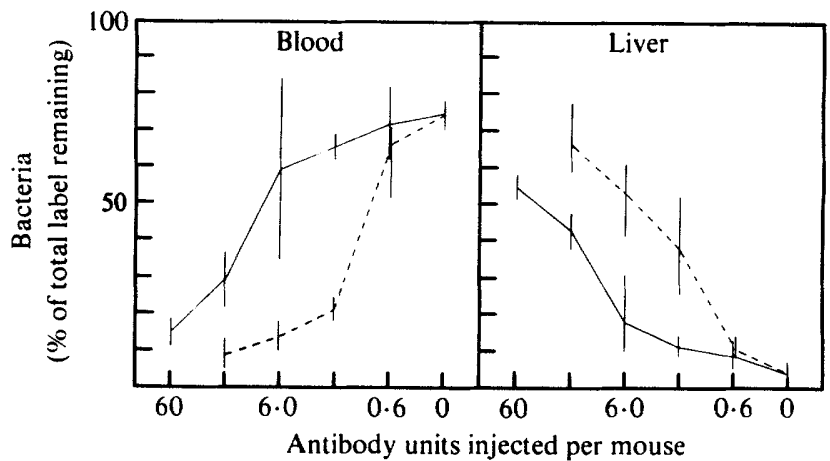

Fig. 2. A quantitative comparison between anti-Salmonella IgG $(-)$ and IgM (-- ) antibodies needed to promote removal of the bacteria from the blood or their uptake into the liver 5 min after IV injection of radiolabelled $S$. typhimurium. The experimental procedure was as described in Fig. 1, except that the mice received graded doses of the antibody fractions IV $1 \mathrm{~h}$ before challenge.

After the first $5 \mathrm{~h}$ a steady state was reached and then the bacterial numbers increased at a slow but even rate over the following days. The apparent rate of growth in the RES was not affected by varying the challenge dose between $10^{5}$ and $10^{7}$ (data not shown). Preinjection of either IgG or IgM increased the initial killing to a minor extent only, and had no effect on subsequent growth.

\section{Effect of antibodies on the kinetics of mouse salmonellosis after IP challenge}

Approximately $2 \times 10^{6}$ bacteria were injected IP, and their subsequent fate monitored by viable counts. There was little killing (or removal) of the bacteria in mice which had not received antibodies, and $60 \%$ of the inoculum could be recovered $1 \mathrm{~h}$ after injection. A large dose (20 antibody units) of either IgG or IgM reduced the number of viable bacteria to approximately $1 \%$ of the inoculum. Titration of the antibody fractions showed that this effect was obtained with 2 units of IgG and $<0.002$ units of IgM. The latter was thus a 1000 -fold more efficient opsonin for intraperitoneal killing - a much larger difference than seen when testing opsonization by the blood clearance assay (Fig. 2). The antibody effect in the peritoneum was restricted to the first hour: over the following $23 \mathrm{~h}$ the bacterial numbers increased slowly, the rates being similar for IgG- and IgM-treated mice.

The initial stages of bacterial appearance in the liver and spleen could not be followed accurately because of contamination of the surfaces of these organs by the peritoneal contents. 
Table 1. Antibody-mediated protection from IP S. typhimurium infection

\begin{tabular}{|c|c|c|c|}
\hline \multirow[b]{2}{*}{ Animal treatment (IP) } & \multicolumn{3}{|c|}{$\begin{array}{l}\text { No. of mouse deaths } \dagger \text { at a } \\
\text { challenge dose of } L D_{50} \times \text { : }\end{array}$} \\
\hline & 100 & 10 & 1 \\
\hline $\begin{array}{l}\text { Saline } \quad 3 \mathrm{~h} \text { before challenge } \\
\text { Antiserum } * 3 \mathrm{~h} \text { before challenge } \\
24 \mathrm{~h} \text { after challenge } \\
48 \mathrm{~h} \text { after challenge }\end{array}$ & $\begin{array}{l}6 \\
3 \\
6 \\
6\end{array}$ & $\begin{array}{l}5 \\
0 \\
6 \\
6\end{array}$ & $\begin{array}{l}4 \\
0 \\
6 \\
6\end{array}$ \\
\hline
\end{tabular}

* $200 \mu \mathrm{l}$ serum K2249 diluted $1: 30$, containing 20 antibody units of both IgG and IgM.

$\uparrow$ No. of mice dead $10 \mathrm{~d}$ after challenge with graded dose of strain SH2183: six mice per group.

However, $1 \mathrm{~d}$ after IP injection there were as many bacteria in these organs as in the peritoneal cavity. When the efficacy of the antibody fractions in reducing the numbers of bacteria in the liver $1 \mathrm{~d}$ after an IP injection was titrated, the result closely paralleled that seen for IP killing. A 100 -fold reduction was effected by the IgM fraction tested at concentrations of $0 \cdot 06,0 \cdot 6,6$ and 60 antibody units. By contrast, only the largest dose, 60 units, of the IgG fraction produced the same effect, whereas doses of $0.06,0.6$ and 6 units gave liver counts indistinguishable from those seen after saline only. The same, maximally 100 -fold reduction was seen with challenge doses varying from $6 \times 10^{4}$ to $2 \times 10^{6}$.

On the subsequent days ( 1 to 4$)$ the bacterial population in the liver and spleen increased slowly in the same manner as seen after IV challenge. This apparent growth was affected little if at all by preinjection of antibodies for each of the doses of IgG or IgM between 0.06 and 60 units.

Thus, the effect of antibodies on IP infection was restricted to the first day after challenge. To test whether this restriction also applied to the protective effect of the antibodies, groups of mice were challenged with IP injection of 10 and $100 \times \mathrm{LD}_{50}$ doses of the bacteria and injected with a high dose of antiserum ( $>20$ antibody units of both IgG and IgM per mouse) either $3 \mathrm{~h}$ before or 24 or $48 \mathrm{~h}$ after the challenge. There was excellent protection from death by the preinjection of antiserum, but none by the later injections (Table 1 ).

\section{DISCUSSION}

The effect of antibodies in mouse salmonellosis is restricted in several ways: (i) it is clearcut against IP but negligible against IV challenge (Mackaness et al., 1966; Jenkin \& Rowley, 1963; Blanden et al., 1966); (ii) it is almost exclusively mediated by the IgM class of anti-Salmonella antibodies (Saxén \& Mäkelä, 1982; Saxén et al., 1984b); and (iii) as shown in the present study, their effect is restricted to the very early phase of the infection. The data presented here help to explain each of these restrictions by showing where in the infectious process the antibodies intervene.

Both the IgM and IgG anti-Salmonella antibodies were active opsonins in the in vivo blood clearance assay. The IgM-promoted uptake of the bacteria must have taken place via the $\mathrm{C} 3 \mathrm{~b}$ receptor of the phagocytes, since macrophages, which are believed to be the main effector cells in Salmonella defence (Akeda et al., 1981; O'Brien et al., 1979 b) do not have receptors for IgM (Bianco et al., 1975). Indeed, uptake of Salmonella by mouse macrophages is promoted by the activation of complement via the alternative pathway without the need of antibodies (LiangTakasaki et al., 1982;1983a). The slow clearance of the bacteria observed in the non-antibodytreated mice ( $50 \%$ in the first $15 \mathrm{~min}$ ) was probably also mediated by $\mathrm{C} 3 \mathrm{~b}$ deposition as a result of a slow activation of the alternative pathway of complement by the LPS of the S. typhimurium (Liang-Takasaki et al., 1983b).

IgM was, as previously known (Robbins et al., 1965), an approximately 10-fold more active opsonin than IgG (Fig. 2), suggesting that it was more effective in activating complement, as shown in other particle-bound systems (Frank et al., 1975; Borsos \& Rapp, 1965). However, even if the antibodies promoted uptake of the opsonized bacteria in the RES, subsequent killing of the bacteria was inefficient and a steady multiplication of the bacteria started very soon (Fig. 3). 


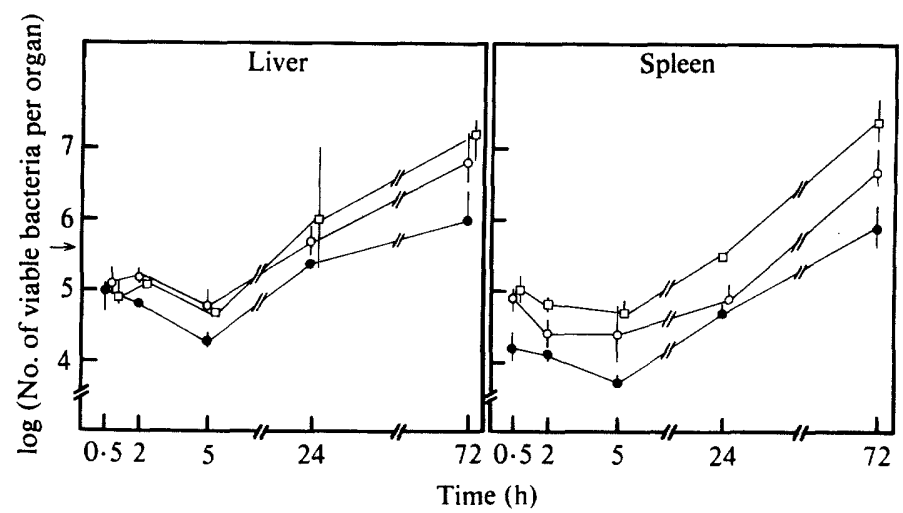

Fig. 3. Effect of 20 antibody units of anti-Salmonella $\operatorname{IgG}(\mathrm{O})$ or $\operatorname{IgM}(\mathrm{O})$ antibodies on the number of live bacteria in the liver or spleen of mice after IV injection of $4 \times 10^{5} \mathrm{~S}$. typhimurium. The control mice received saline ( $\square$ ). The challenge dose is indicated by an arrow. Each point represents the geometric mean of results for three mice.

Table 2. Comparison of the efficacy of the $\operatorname{Ig} M$ and $\operatorname{Ig} G$ fractions of anti-Salmonella serum in different effector functions

\begin{tabular}{|c|c|c|c|}
\hline \multirow[b]{2}{*}{ Effector function } & \multirow{2}{*}{$\begin{array}{l}\text { Challenge } \\
\text { route }\end{array}$} & \multicolumn{2}{|c|}{ No. of units required } \\
\hline & & $\mathrm{IgG}$ & IgM \\
\hline $\begin{array}{l}50 \% \text { Clearance within } 5 \text { min (Fig. } 3 \text { ) } \\
>90 \% \text { Reduction of bacteria in peritoneal fluid } \\
99 \% \text { Reduction of bacteria in liver } \\
50 \% \text { Protection after challenge with } 10 \times \text { LD }_{50}{ }^{*}\end{array}$ & $\begin{array}{l}\text { IV } \\
\text { IP } \\
\text { IP } \\
\text { IP }\end{array}$ & $\begin{array}{r}12 \\
2 \\
60 \\
11\end{array}$ & $\begin{aligned} & 1.2 \\
< & 0.002 \\
\leqslant & 0.06 \\
& 0.015\end{aligned}$ \\
\hline
\end{tabular}

* See Saxén \& Mäkelä (1982).

When the bacteria were injected IP into non-immune mice, the numbers of bacteria recovered $1 \mathrm{~h}$ after challenge were close to those of the inoculum, indicating that unopsonized bacteria were not removed or killed in the peritoneum. Preinjection of antibodies caused a rapid decline in the numbers of viable bacteria in the peritoneal cavity, and $\operatorname{IgM}$ was $>1000$-fold more efficient than IgG. These data are in accord with previous findings (Rowley \& Turner, 1966; Briles et al., 1981), which also showed, by comparing viable bacterial counts with radioactive label, that the opsonized bacteria were killed and not just lost from the sample. As discussed above, the IgM could only act via complement activation, and these results suggest a primary role for $\mathrm{C} 3 \mathrm{~b}$ in killing of opsonized salmonellae in the peritoneal cavity.

The antibody-dependent early reduction in bacterial numbers in the peritoneal cavity could in fact explain the whole protective effect of the antibodies. It led to a reduced initial number of bacteria in the liver and spleen, the main sites of bacterial multiplication in mouse salmonellosis (Collins, 1969). Since the intracellular growth rate was not affected, this resulted in a reduced final number of bacteria and protection from death. Indeed, both the qualitative and quantitative antibody requirements for the intraperitoneal killing of the bacteria and the protective effect were very similar (Table 2).

Considering the often expressed doubts about a protective effect of antibodies in mouse salmonellosis, the very small amounts of IgM that were active against IP challenge (Table 2) are remarkable. The protective dose of 0.015 antibody units corresponds to $1 \mathrm{ml}$ of a 1 in 200000 dilution of the rabbit immune serum. Rowley \& Turner (1966) showed that a corresponding rabbit anti-Salmonella serum had $66 \mu \mathrm{g}$ protein in the IgM fraction from $1 \mathrm{ml}$ anti-O serum, and promoted killing of IP injected salmonellae at a dilution of 1 in 500000 . From these figures they calculated that eight molecules of IgM (but 2000 molecules of $\mathrm{IgG}$ ) per bacterium were sufficient for opsonization. 
A comparison of the infection kinetics after IV and IP challenge showed that in both cases the main site of bacterial multiplication was the RES where the apparent growth rate of the bacteria between 1 and $4 \mathrm{~d}$ after infection was the same. The only difference was in the early handling of the bacteria: the macrophages in the liver and spleen were inefficient at killing the bacteria they ingested (and the killing was not improved by opsonization) whereas in the peritoneum the bacteria were efficiently killed. The latter were, however, dependent on opsonization via IgM and complement. The effector cells in the peritoneum capable of causing (in co-operation with complement) the observed killing of salmonellae were, however, not identified and experiments to elucidate this question are in progress.

I wish to thank Marianne Hovi for excellent assistance in the mouse experiments, $O$. Mäkelä for help with the antiserum, Kaija Helisjoki for secretarial help and P. H. Mäkelä for constructive criticism. Harri Saxén is a recipient of a fellowship from Emil Aaltonen Foundation.

\section{REFERENCES}

Akeda, H., Mitsuyama, M., Tatsukawa, K., Nomoto, K. \& TAKeYA, K. (1981). The synergistic contribution of macrophages and antibody to protection against Salmonella typhimurium during the early phase of infection. Journal of General Microbiology 123, 209-214.

Bianco, C., Griffin, F. M., Jr \& Silverstein, S. C. (1975). Studies of the macrophage complement receptor. Alteration of receptor function upon macrophage activation. Journal of Experimental Medicine 141, 1278-1283.

Brozzı, G. (1972). Differential susceptibility of high and low antibody producing mouse lines to infection and tumour transplantation. In Genetic Control of Immune Responsiveness, pp. 317-327. Edited by $\mathrm{H}$. O. McDevitt \& M. Landy. New York: Academic Press.

Blanden, R. V., Mackaness, G. B. \& Collins, F. M. (1966). Mechanisms of acquired resistance in mouse typhoid. Journal of Experimental Medicine 124, 585600.

Borsos, T. \& RAPP, H. J. (1965). Complement fixation on cell surfaces by $19 \mathrm{~S}$ and $7 \mathrm{~S}$ antibodies. Science 150, 505-506.

Briles, D. E., Lehmayer, J. \& Forman, C. (1981). Phagocytosis and killing of Salmonella typhimurium by peritoneal exudate cells. Infection and Immunity 33, 380-388.

Collins, F. M. (1969). Effect of immune mouse serum on the growth of Salmonella enteritidis in nonvaccinated mice challenged by various routes. Journal of Bacteriology 97, 667-675.

Collins, F. M., Mackaness, C. B. \& Blanden, R. V. (1966). Infection-immunity in experimental salmonellosis. Journal of Experimental Medicine 124, 601619.

Frank, M. M., Schreiber, A. D. \& Atkinson, J. P. (1975). Studies of the interaction of antibody complement, and macrophages in the immune clearance of erythrocytes. In The Phagocytic Cell in Host Resistance, pp. 101-115. Edited by J. A. Bellanti \& D. H. Dayton. New York: Raven Press.

Fraker, P. J. \& SpeCK, J. C., JR (1978). Protein and cell membrane iodinations with a sparingly soluble cloroamide, 1,3,4,6-tetrachloro-3 $\alpha, 6 \alpha$, diphenylglycoluril. Biochemical and Biophysical Research Communications 80, 849-853.
Hoiseth, S. K. \& Stocker, B. A. D. (1981) Aromaticdependent Salmonella typhimurium are non-virulent and effective as live vaccines. Nature, London 291, 238-239.

Hormaeche, C. E., Brok, J. \& Pettifor, R. (1980). Natural resistance to mouse-typhoid: Possible role of the macrophage. In Genetic Control of Natural Resistance to Infection and Malignancy, pp. 121-131. Edited by E. Skamene, P. A. L. Kongshavn \& M. Landy. New York: Academic Press.

Jenkin, C. R. \& Rowley, D. (1963). Basis for immunity to typhoid in mice and the question of "cellular immunity". Bacteriological Reviews 27, 391404.

Jenkin, C. R. \& Rowley, D. (1965). Partial purification of the "protective" antigen of Salmonella typhimurium and its distribution amongst various strains of bacteria. Australian Journal of Experimental Biology and Medical Sciences 43, 65-71.

Krishnapillai, V. \& Karthigasu, K. (1969). Salmonella abony-Salmonella typhimurium recombinant nonvirulent for the mouse. Journal of Bacteriology 97 , 1343-1351.

LEVINE, M. M. \& HoRNICK, R. B. (1981). Immunology of enteric pathogens, Salmonella, Shigella, and Escherichia coli. In Immunology of Human Infection, pp. 249-290. Edited by A. J. Nahmias \& R. J. O'Reilly. New York: Plenum.

Liang-Takasaki, C.-J., Märelä, P. H. \& Leive, L. (1982). Phagocytosis of bacteria by macrophages: changing the carbohydrate of lipopolysaccharide alters interaction with complement and macrophages. Journal of Immunology 128, 1229-1233.

Liang-Takasaki, C.-J., Saxén, H., Mäkelä, P. H. \& LeIVE, L. (1983a). Complement activation by polysaccharide of lipopolysaccharide: an important virulence determinant of Salmonellae. Infection and Immunity 41, 563-569.

Liang-Takasaki, C.-J., Grossman, N. \& Leive, L. $(1983 b)$. Salmonellae activate complement differentially via the alternative pathway depending on the structure of their lipopolysaccharide O-antigen. Journal of Immunology 130, 1867-1870.

Mackaness, G. B., Blanden, R. V. \& Collins, F. M. (1966). Host-parasite relations in mouse typhoid. Journal of Experimental Medicine 124, 573-583.

Miller, J. H. (1972). Experiments in Molecular 
Genetics. New York: Cold Spring Harbor Laboratory.

O'Brien, A. D., Scher, I., Campbell, G. H., MaCDermotr, R. P. \& Formal, S. B. (1979a). Susceptibility of CBA/N mice to infection with Salmonella typhimurium: Influence of the $\mathrm{X}$-linked gene controlling B lymphocyte function. Journal of Immunology 123, 720-740.

O'Brien, A. D., SCher, I. \& Formal, S. B. (1979b). Effect of silica on the innate resistance of inbred mice to Salmonella typhimurium infection. Infection and Immunity 25, 513-520.

Ørskov, J. \& MoltKe, O. (1928). Studien über den Infektionsmechanismus bei verschiedenen Paratyphus-Infektionen an weissen Mäusen. Zeitschrift für Immunitätsforschung 59, 357-405.

Ørskov, J., Jensen, K. A. \& Kobayashi, K. (1928). Studien über die Bedeurung der Breslaumfelstron der Mäuse speziell mit Rücksicht auf die Bedeutung des Retikuloendothelialgewebes. Zeitschrift für Immunitätsforschung 55, 34-68.

Plant, J. E. \& GlynN, A. A. (1976). Genetics of resistance to infection with Salmonella typhimurium in mice. Journal of Infectious Diseases 133, 72-78.

RoANTree, R. J. (1967). Salmonella $O$ antigen and virulence. Annual Review of Microbiology 21, 443446.
Robins, J. B., KenNy, K. \& SUTER, E. (1965). The isolation and biological activities of rabbit IgM- and IgG-anti-Salmonella typhimurium antibodies. Journal of Experimental Medicine 122, 385-401.

Rowley, D. \& TURNer, K. J. (1966). Number of molecules of antibody required to promote phagocytosis of one bacterium. Nature, London i, 496-497.

SAXÉn, H. \& MÄKelÄ, O. (1982). The protective capacity of immune sera in experimental mouse salmonellosis is mainly due to IgM antibodies. Immunology Letters 5, 267-272.

SAXén, H., Hovi, M. \& Mäkelä, P. H. (1984a). Lipopolysaccharide and mouse virulence of Salmonella: $O$ antigen affects phagocytic killing and virulence after intraperitoneal but not intravenous challenge. FEMS Letters (in the Press).

SaXé, H., MÄKelÄ, O. \& Svenson, S. B. (1984b). Isotype of protective anti-Salmonella antibodies. Infection and Immunity (in the Press).

VALTONEN, V. V. (1970). Mouse virulence of Salmonella strains: the effect of different smooth-type O-side chains. Journal of General Microbiology 64, 255-268.

WEBSTER, L. T. (1937). Inheritance of resistance of mice to bacterial and neurotropic virus infections. Journal of Experimental Medicine 65, 261-274. 